\title{
Immediate effects of maternal deprivation on the (re)activity of the HPA-axis differ in CD1 and C57BI/6J mouse pups
}

\author{
Nikolaos P. Daskalakis ${ }^{1,2,3,4,5}$ *, Leo Enthoven ${ }^{1}$, Edwige Schoonheere ${ }^{1}$, Edo Ronald de Kloet ${ }^{1,2}$ and \\ Melly S. Oitzl ${ }^{1,6}$
}

\begin{abstract}
${ }^{1}$ Division of Medical Pharmacology, Leiden Academic Center for Drug Research, Leiden University, Leiden, Netherlands
${ }^{2}$ Department of Endocrinology and Metabolism, Leiden University Medical Center, Leiden University, Leiden, Netherlands

${ }^{3}$ Traumatic Stress Studies Division, Department of Psychiatry, Icahn School of Medicine at Mount Sinai, New York, NY, USA

${ }^{4}$ Laboratory of Molecular Neuropsychiatry, Department of Psychiatry, Icahn School of Medicine at Mount Sinai, New York, NY, USA

${ }^{5}$ PTSD Research Program, Mental Health Patient Care Center, James J. Peters Veterans Affairs Medical Center, Bronx, NY, USA

${ }^{6}$ Center for Neuroscience, Swammerdam Institute for Life Sciences, University of Amsterdam, Amsterdam, Netherlands
\end{abstract}

\section{Edited by:}

Mitsuhiro Kawata, Kyoto Prefectural

University of Medicine, Japan

\section{Reviewed by:}

Aldo Lucion, Universidade Federal do

Rio Grande do Sul, Brazil

Gábor B. Makara, Hungarian Academy

of Sciences, Hungary

\section{*Correspondence:}

Nikolaos P. Daskalakis, Laboratory of

Molecular Neuropsychiatry and

Traumatic Stress Studies Division,

Department of Psychiatry, Icahn

School of Medicine at Mount Sinai,

One Gustave L. Levy Place, Box

1668, New York, NY 10029-6574, USA

e-mail:nikolaos.daskalakis@

mssm.edu
The postnatal development of the mouse is characterized by a period of hyporesponsiveness of the hypothalamic-pituitary-adrenal (HPA) axis to mild stressors. Maternal deprivation (MD) during this period can disrupt the quiescence of the HPA-axis. The present study examined the influence of strain (outbred CD1 vs. inbred C57BL/6J mice) on some central and peripheral components of the HPA-axis in neonatal mice (5-day-old) in the presence of their mother or after $24 \mathrm{~h} \mathrm{MD}$ (on postnatal day 4) under basal or mild stressful conditions. In the presence of the dam, adrenal corticosterone (CORT) secretion was low in both mouse strains. Compared to CD1 mice, C57BL/6J had lower CORT levels associated with higher $\mathrm{ACTH}$ levels and $\mathrm{ACTH} / \mathrm{CORT}$ ratio (i.e., lower adrenal sensitivity to ACTH), and higher glucocorticoid receptor (GR) mRNA expression in the paraventricular nucleus. Although MD disinhibited the HPA-axis in both strains as reflected by increased basal CORT and ACTH, we found a strain-dependent pattern. MD increased CORT more in C57BL/6J compared to CD1 mice together with a lower $A C T H / C O R T$ ratio (i.e., higher adrenal sensitivity to ACTH), while GR mRNA was no longer different in the two strains. However, this increased adrenal sensitivity in maternally deprived C57BL/6J mice was not reflected in their CORT response to a subsequent novelty stressor, possibly due to an MD-induced ceiling effect in their steroidogenic capacity. In conclusion, the immediate outcome of MD depends on the genetic background of the mother-infant dyad, suggesting that maybe also the outcome in later-life cannot be generalized.

Keywords: hypothalamic-pituitary-adrenal axis, corticosterone, ACTH, CRH, GR, neonate, maternal deprivation, genetic

\section{INTRODUCTION}

Maternal stimuli play a central role in the postnatal development of the hypothalamic-pituitary-adrenal axis (HPA-axis) in rodents $(1,2)$ especially during the stress-hyporesponsive period (SHRP). The SHRP lasts from postnatal day (pnd) 1-12 in mice, (pnd 3-14 in rats) and is characterized by low basal levels of corticosterone (CORT) and an inability to elicit a CORT response to mild stress $(3,4)$. Rodent dams do not leave often their nest for longer than 15-20 min during the SHRP (5). Removal of the mother for prolonged time periods ( $>3-8$ to $24 \mathrm{~h}$ ) has been shown to activate the HPA-axis, while the axis also becomes responsive to mild stressors, which may modulate ongoing developmental programs $(6,7)$.

Large individual variations in the long-term biobehavioral outcome of early-life traumatic experiences have been reported in humans (8) and rodents $(9,10)$. This raised the idea that early-life trauma might shape pre-existing genetic vulnerability to certain stressful conditions in later life (11). Maternal deprivation (MD) is a commonly used animal paradigm to study the consequences of early-life trauma on adult stress-responses and related behaviors (12). The MD paradigm has been applied in various designs ranging from single $24 \mathrm{~h}$ deprivations to repeated daily separations in time periods ranging between 3 and $8 \mathrm{~h}(9,11)$.

Most of our knowledge on the effects of MD on HPA-axis and stress-related behaviors is based on research in outbred rodent strains. Although it is known that genetically selected lines of rats display differential sensitivity to the long-term effects of MD (13-15), the aspect of genetic predisposition has been given little attention. In recent experiments, we showed that responsiveness to mild stressors following prolonged maternal absence is strain-dependent (16). We actually observed that while maternally separated pups (i.e., repeatedly for $8 \mathrm{~h}$ ) habituate toward the maternal absence per se by displaying low basal CORT levels (16-18), their CORT response toward a subsequent heterotypic stressor sensitizes in a strain-dependent fashion: deprived Long Evans pups were more re-active to the subsequent stressor than similarly deprived Wistar rats (16). 
The inbred C57BL/6J mouse strain is most widely used as genetic background strain for engineering genetic mouse models for human diseases. A few studies compared C57BL/6J mice with common outbred mice strains (e.g., CD1 mice) on stress-related physiology and behavior. C57BL/6J and CD1 mice have differences in their circadian pattern of the stress-response (19). C57BL/6J mice have lower stress responsiveness in a light/dark exploration test for anxiety (20) and display a reduced exploration in a novel environment (21). Furthermore, CD1 mice showed better avoidance learning in a Y-maze task (22). Interestingly, C57BL/6J and CD1 mice seem to display differences on the long-term outcome of maternal separation on the stress-response, cognitive performance, anxiety/depression-like, or schizophrenia-like behaviors (23-33). Generally, the reported effects indicate more often significant effects in C57BL/6J than in CD1 mice.

Studying the immediate effects of MD on the development of the stress system responsiveness might give insights on the salient factors that influence the long-term outcome. This is an approach proven to be successful using a variety of early-life stress paradigms $(18,34)$. In the current study, we compared C57BL/6J with CD1 mouse pups with regard to the immediate effects of pnd 4 MD on HPA-axis stress reactivity.

\section{MATERIALS AND METHODS \\ ANIMALS}

Offspring of CD1 and C57BL/6J mice were used in this study. All mice were housed under a 12:12 h light/dark cycle (lights on at 07:00 hours) and constant temperature $\left(23 \pm 2^{\circ} \mathrm{C}\right)$ and humidity $(55 \pm 5 \%)$ conditions. Food (SRM-A; Hope Farms, Woerden, The Netherlands) and water $\left(172 \mathrm{ml} \mathrm{HCl} / 200 \mathrm{H} \mathrm{H}_{2} \mathrm{O}\right)$ was provided ad libitum. Three females were mated with one male in polycarbonate boxes $\left(820 \mathrm{~cm}^{3}\right)$ containing sawdust bedding. Pregnant females were transferred to clean polycarbonate cages containing sawdust and two sheets of paper towels for nesting material. Pregnant females were checked for litters daily between 09:00 and 10:00 hours. If litters were found, the day of birth was defined as day 0 for that litter. On the day after parturition, day 1, each litter was culled to eight healthy pups (four males and four females) for the CD1 strain and to six healthy pups (three males and three females) for the C57BL/6J strain and then remained undisturbed until used in the experiment. A total of four CD1 litters and six C57BL/6J litters were used in the study. Animal experiments were approved by the Local Committee for Animal Health, Ethics, and Research of Leiden University and carried out in accordance with European Communities Council Directive 86/609/EEC.

\section{EXPERIMENTAL DESIGN}

At postnatal day 4, mothers from nests randomly selected for MD (two CD1 and three C57BL/6J nests) were removed from the home cage. The home cage containing the pups was transferred to an adjacent room with similar light and temperature conditions and placed on a heating pad set at $30-33^{\circ} \mathrm{C}$. Neither food nor water was available during MD. At pnd 5, half of the non-deprived (NON-DEP) and half of the deprived (DEP) pups were decapitated immediately to provide a basal sample for measurements in blood and brain. The remaining NON-DEP and DEP pups were placed individually in novel cages containing clean sawdust bedding on heating pads set at $30-33^{\circ} \mathrm{C}$ and decapitated after $30 \mathrm{~min}$ to provide a novelty stress sample.

\section{BLOOD PROCESSING AND HORMONE DETERMINATION}

Trunk blood from all decapitated pups was collected in EDTA-coated microcentrifuge tubes; plasma was extracted and stored frozen at $-20^{\circ} \mathrm{C}$ until hormone determination. ACTH was measured by radioimmunoassay (RIA; MP Biomedicals, LLC, NY, USA; sensitivity $10 \mathrm{pg} / \mathrm{ml}$, intra-assay variation $4.1 \%$, inter-assay variation $4.4 \%$ ) as described before (16). CORT was measured by RIA (MP Biomedicals, LLC, NY, USA; sensitivity $1.25 \mathrm{ng} / \mathrm{ml}$, intra-assay variation, $4.4 \%$, interassay variation $6.5 \%$ ) as described before (16). We calculated the ratio of ACTH to CORT as an indirect measure of adrenal sensitivity to ACTH (18).

\section{IN SITU HYBRIDIZATION}

Frozen brains and pituitaries were sectioned at $-20^{\circ} \mathrm{C}$ in a cryostat microtome at $16 \mu \mathrm{m}$ in the coronal plane. Sections were thaw-mounted on poly-L-lysine coated slides, air-dried, and kept at $-80^{\circ} \mathrm{C}$. In situ hybridization using $35 \mathrm{~S}$-UTP labeled ribonucleotide probes [CRH and glucocorticoid receptor (GR)] was performed as described previously $(17,18)$. The slides were opposed to Kodak Biomax MR film (Eastman Kodak Co., Rochester, NY, USA) and developed. Autoradiographs were digitized, and relative expression of $\mathrm{CRH}$ and GR mRNA was determined by computer-assisted optical densitometry (analysis 3.1, Soft Imaging System GmbH, Münster, Germany). The mean of four to six measurements was calculated for each mouse.

\section{STATISTICS}

Data were analyzed by analysis of variance (ANOVA) using strain (CD1 or $\mathrm{C} 57 \mathrm{BL} / 6 \mathrm{~J})$, treatment (NON-DEP or DEP), and time (basal or novelty) as fixed factors. When appropriate, post hoc Tukey test was performed. The initial analysis included sex as a factor; once it was determined that sex was not a significant factor, the data were collapsed across this variable. The level of significance was set at $P<0.05$. Data are presented as mean \pm SEM.

\section{RESULTS}

\section{WEIGHT}

Two-way ANOVA revealed main effects of strain $\left(F_{1,64}=141.34\right.$; $p<0.001)$ and treatment $\left(F_{1,64}=141.34 ; p<0.001\right)$. C57BL/6J were lighter than CD1 mice $(p<0.001)$ in both treatment conditions (Table 1). DEP pups were lighter than NON-DEP pups $(p<0.001$ for both strains).

Table 1 | Body weight (grams) of non-deprived (NON-DEP) and $24 \mathrm{~h}$ deprived (DEP) pups in CD1 and C57BL/6J mice at postnatal day 5.

\begin{tabular}{|c|c|c|c|c|c|c|c|}
\hline \multirow[t]{2}{*}{ Strain } & \multicolumn{3}{|c|}{ NON-DEP } & \multicolumn{3}{|c|}{ DEP } & \multirow[t]{2}{*}{$\%$ Change } \\
\hline & Mean & $N$ & SEM & Mean & $N$ & SEM & \\
\hline CD1 & 3.15 & 16 & 0.06 & $2.51^{\#}$ & 16 & 0.08 & $\downarrow 20$ \\
\hline C57BL/6J & $2.51^{\$}$ & 16 & 0.10 & $1.78^{\# \$}$ & 17 & 0.11 & $\downarrow 29$ \\
\hline
\end{tabular}

Data represent mean \pm SEM. \# vs. NON-DEP, \$ vs. CD1.

Significance level was set at $p=0.05$. 


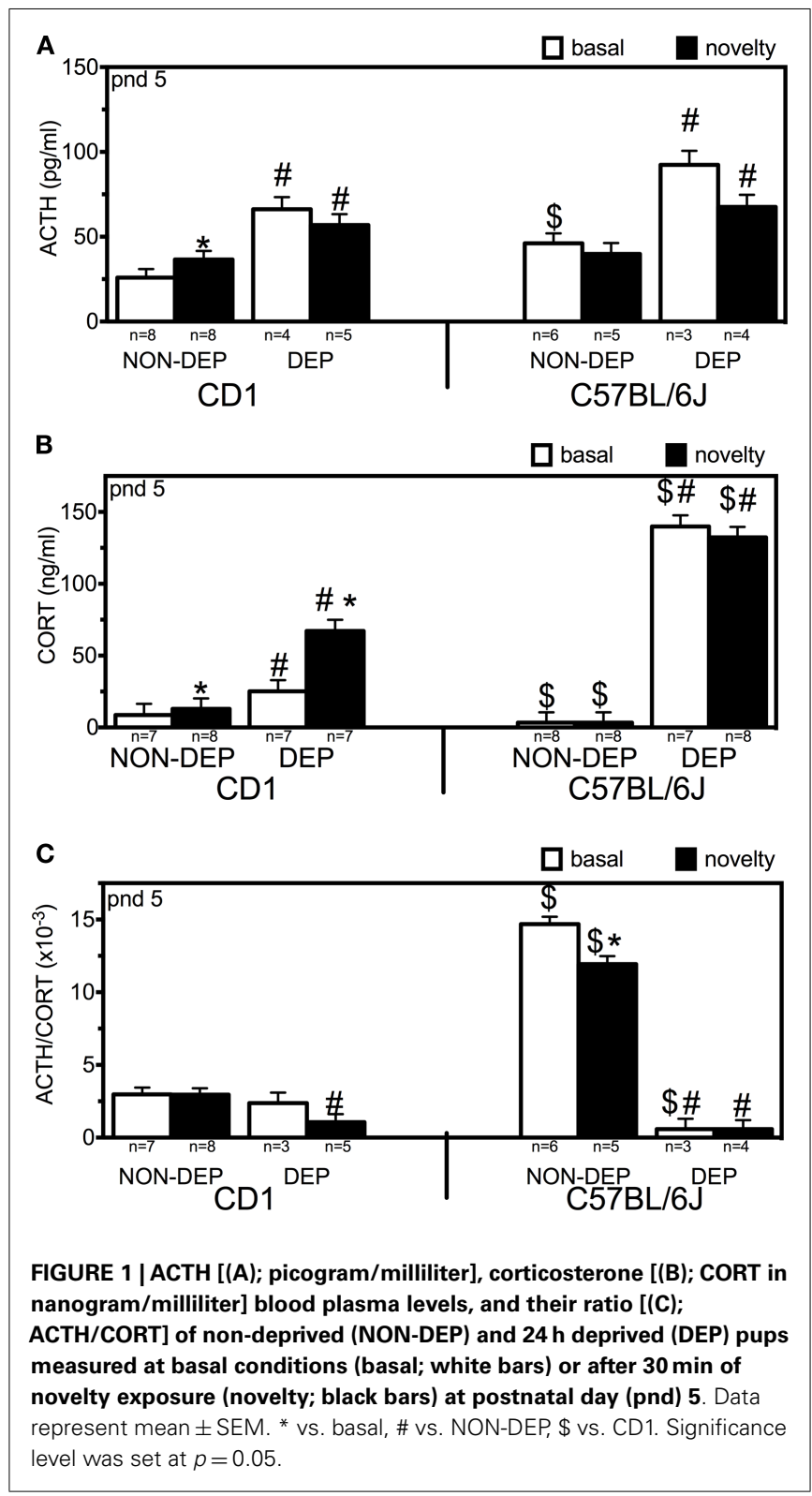

\section{АCTH}

Three-way ANOVA revealed main effects of strain $\left(F_{1,42}=10.79\right.$; $p<0.001)$, treatment $\left(F_{1,42}=53.65 ; p<0.001\right)$, and interaction of treatment and time $\left(F_{1,42}=4.41 ; p=0.043\right)$ (Figure 1A). Strain differences were found at NON-DEP basal levels $(p=0.005)$. Novelty exposure increased ACTH levels in CD1 ( $41 \%$, $p=0.025$ ) but not in C57BL/6J mice. After $24 \mathrm{~h} \mathrm{MD,} \mathrm{ACTH} \mathrm{basal}$ levels were elevated $(\uparrow 156 \%, p=0.001$ for $\mathrm{CD} 1 ; \uparrow 100 \%, p=0.006$ for $\mathrm{C} 57 \mathrm{BL} / 6 \mathrm{~J})$. Subsequent novelty exposure did not produce further increase in ACTH in either CD1 or C57BL/6J mice, while in both strains ACTH levels were higher than the respective NON-DEP levels ( $p=0.010$ for CD1, $p=0.040$ for C57BL/6J).

\section{CORTICOSTERONE}

Three-way ANOVA revealed main effects of strain $\left(F_{1,59}=59.86\right.$; $p<0.001)$, treatment $\left(F_{1,59}=248.76 ; p<0.001\right)$, interaction strain and treatment $\left(F_{1,59}=83.52 ; p<0.001\right)$, interaction strain and time $\left(F_{1,59}=6.38 ; p=0.015\right)$, and interaction of strain, treatment, and time $\left(F_{1,59}=4.50 ; p=0.039\right)$ (Figure 1B). Novelty exposure increased CORT levels in CD1 ( $50 \%, p=0.002)$ but not in C57BL/6J mice. After $24 \mathrm{~h} \mathrm{MD}$, CORT basal levels were elevated in both strains ( $\uparrow 191 \%, p<0.001$ for CD1; $\uparrow 4099 \%$, $p<0.001$ for $\mathrm{C} 57 \mathrm{BL} / 6 \mathrm{~J})$. Subsequent novelty exposure further increased CORT only in CD1 mice (additional $\uparrow 167 \%, p<0.001$ ), while in both strains CORT levels were higher than the respective NON-DEP levels $(p<0.001)$. Strain differences were found at all four conditions: C57BL/6J CORT levels being lower than in CD1 at NON-DEP conditions ( $p<0.001$ for both basal and novelty), and higher at DEP conditions (for basal: $p<0.001$, for novelty: $p=0.003)$.

\section{ACTH/CORT RATIO}

Three-way ANOVA revealed main effects of strain $\left(F_{1,40}=126.05\right.$; $p<0.001)$, treatment $\left(F_{1,40}=290.46 ; \quad p<0.001\right)$, time $\left(F_{1,40}=6.24 ; p=0.018\right)$, interaction strain and treatment $\left(F_{1,40}=196.03 ; p<0.001\right)$, and interaction of strain, treatment, and time $\left(F_{1,40}=6.12 ; p=0.019\right)$ (Figure 1C). At NON-DEP basal conditions, C57BL/6J displayed much higher ACTH/CORT than CD1 mice $(\uparrow 393 \%, p<0.001)$. Novelty exposure decreased the ratio in $\mathrm{C} 57 \mathrm{BL} / 6 \mathrm{~J}(\downarrow 19 \%, p=0.048)$ but not in CD1 mice. After $24 \mathrm{~h} \mathrm{MD}$, ACTH/CORT ratio decreased in C57BL/6J $(\downarrow 96 \%$, $p<0.001)$ but not in CD1 mice in such an extent that the C57BL/6J displayed even less ratio than CD1 mice $(p=0.029)$. For both strains, ACTH/CORT ratios after subsequent novelty exposure were lower than the respective NON-DEP levels (CD1: $p=0.004$, C57BL/6J: $p<0.001)$.

\section{CRH mRNA EXPRESSION IN THE PVN}

Two-way ANOVA revealed main effects of treatment $\left(F_{1,30}=5.41\right.$; $p=0.028$ ) (Figure 2A). Twenty-four hours of MD downregulated CRH mRNA $(p=0.036)$ in CD1 mice but not in C57BL/6J.

\section{GR mRNA EXPRESSION IN THE PVN}

Two-way ANOVA revealed main effects strain $\left(F_{1,27}=10.77\right.$; $p=0.003)$, treatment $\left(F_{1,27}=17.97 ; p<0.001\right)$, and interaction of strain and treatment $\left(F_{1,27}=5.02 ; p=0.035\right)$ (Figure 2B). At basal conditions, C57BL/6J displayed higher levels of GR mRNA than CD1 mice $(p=0.002)$. Twenty-four hours of MD downregulated GR mRNA in C57BL/6J $(p<0.001)$.

\section{GR mRNA EXPRESSION IN PITUITARY (DATA NOT SHOWN)}

There were no main effects of strain or treatment on GR mRNA in pituitary.

\section{DISCUSSION}

Our data show that the two mouse strains, CD1 and C57BL/6J mice, differ in the neonatal HPA-axis activity at basal conditions as well as after a $24 \mathrm{~h} \mathrm{MD}$ period.

Regarding basal HPA-axis activity, C57BL/6J displayed higher ACTH and lower CORT than CD1 mice, indicating lower basal adrenal sensitivity to ACTH as reflected by a higher ACTH/CORT ratio. Additionally, basal GR mRNA expression in the PVN is higher than in CD1 mice. We propose that this increased GR 


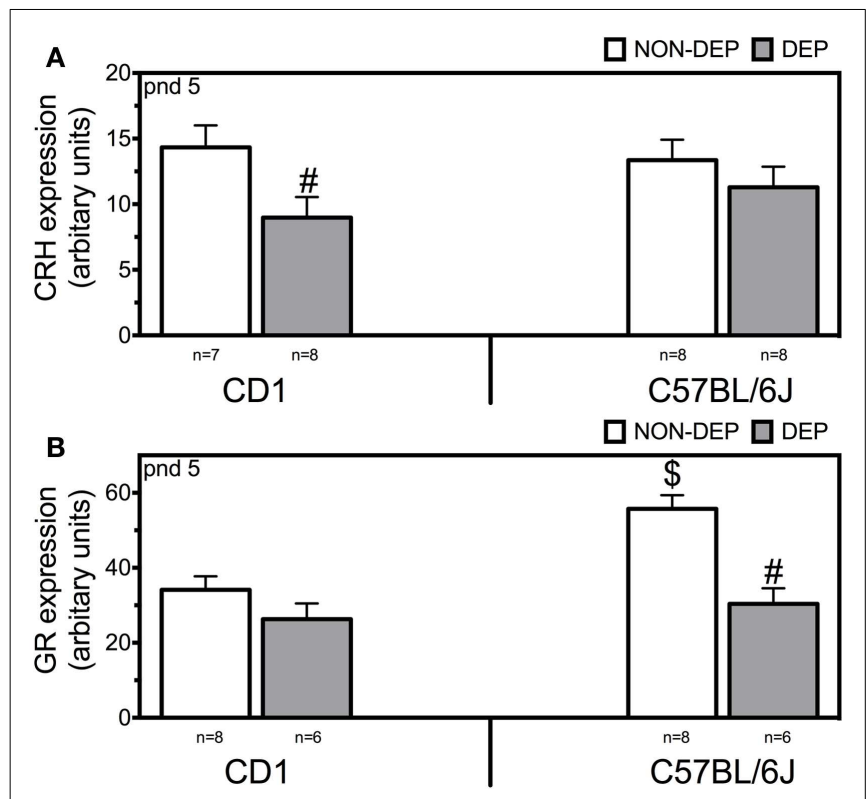

FIGURE 2 | CRH (A) and GR (B) mRNA expression in the paraventricular nucleus of the hypothalamus measured in non-deprived (NON-DEP) and deprived (DEP) mice at postnatal day (pnd) 5. Data represent mean \pm SEM. \# vs. NON-DEP, \$ vs. CD1. Significance level was set at $p=0.05$.

mRNA expression might be a result of the lower CORT production. The higher GR mRNA is not likely to be an indication of stronger negative feedback capacity because there was no strain difference in basal CRH mRNA expression in the PVN or GR mRNA expression in the pituitary. Exposure of NON-DEP pups to novelty resulted in a subtle statistically significant rise in both ACTH and CORT in CD1 mice only. This finding underlines strain-dependent effects and confirms that the SHRP is a period of stress-hypo-responsiveness (3).

Maternal deprivation elicited in both strains the expected increase of ACTH (35) and CORT $(35,36)$. ACTH rose at a similar extent in both strains. CORT levels were dramatically increased in C57BL/6J compared to a more moderate increase in CD1 pups. Previous findings in rats showed that during the time-course of $24 \mathrm{~h}$ maternal separation, adrenal sensitivity to stress increased (37) through increases in melanocortin type 2 receptors for ACTH (16) or other mechanisms (38) in a strain-dependent manner (16). The decrease in ACTH/CORT ratio in C57BL/6J compared to $\mathrm{CD} 1$ pups (from higher ACTH/lower CORT to comparable $\mathrm{ACTH} /$ higher CORT) indicates that, C57BL/6J after MD are no longer less sensitive to ACTH than CD1 mice at the adrenal level, but actually they display increased adrenal sensitivity compared to CD1 mice. In that, CORT secretion may be influenced also by factors other than $\mathrm{ACTH}$, direct measures of neonatal adrenal sensitivity to ACTH need to be undertaken in future experiments. Only CD1 mice displayed a CORT response to novelty stress after MD. The absence of an additional novelty-induced CORT increase in C57BL/6 might be related to a ceiling effect in their steroidogenic capacity.
It is interesting that $\mathrm{C} 57 \mathrm{BL} / 6 \mathrm{~J}$ do not show the expected reduction in CRH mRNA expression following MD $(35,39)$ that was seen in the CD1 pups. This might be associated with the reduction in GR mRNA expression in the PVN and, thus, with potentially less efficient negative feedback actions of CORT at the cells that produce and release $\mathrm{CRH}$. This might be an indication that, in C57BL/6J, MD causes a greater disruption of SHRP, which is characterized by enhanced negative feedback (40).

Another contributing factor to the strain differences here might be the transcortin levels and ultimately the free (biologically active) CORT, which is the HPA-axis feedback signal. RIA does not distinguish between free and transcortin-bound cortisol. Transcortin levels are low during SHRP (41) and strain differences are possible. Peripheral and central metabolic factors (e.g., blood glucose, arcuate nucleus NPY) can also mediate the activation of the HPA-axis induced by maternal separation $(42,43)$. Indeed, in terms of body weight changes, MD caused the greatest metabolic challenge in C57BL/6J pups, which also displayed the highest activation of the HPA-axis expressed by CORT. Other factors not related to feeding might be also involved. Actually feeding is more related with the adrenal CORT secretion and tactile stimulation more related to pituitary ACTH release (1).

We have to acknowledge some limitations of the study. Preweaning pups from small litters ( $<5$ pups) have higher body weight and higher basal CORT levels than pups from large litters (>15 pups) (44). The C57BL/6J litters are naturally smaller in size than the CD1 litters. This has created an unavoidable, without cross-fostering, confound that might have interfered with the strain differences reported. We opted for an equal sex-ratio (1:1) that removed the sex-ratio bias. Nevertheless, the litter-size difference between the strains was small (two pups) and did not seem to have a noticeable effect; in this experiment, the pups of the C57BL/6J strain (with the smaller litter size of six pups) displayed lower body weight and lower basal CORT than the pups of the CD1 strain (with the larger litter size of eight pups). Future studies could illuminate the role of litter-size, but also of the basal mother-pup interactions and other related epigenetically mediated mechanisms (45) on the neonatal basal and post-MD HPA-axis activity.

Specific genetic contributions could be clarified in the future with the use of transgenic mice, but the strain differences in immediate effects of MD observed, here, in mice and, previously, in rats (16) emphasize the importance of genetic background on the effects of early maternal environment on the development of the stress system. Late-life consequences may also depend on genetic background, but this remains to be tested.

\section{ACKNOWLEDGMENTS}

This work was supported by the Top Institute of Pharmaceutical Sciences T5\#209 (Edo Ronald de Kloet, Nikolaos P. Daskalakis), NWO-NDRF/STIGON (Leo Enthoven), Royal Netherlands Academy of Arts and Sciences (Edo Ronald de Kloet), NWO-Aspasia (Melly S. Oitzl), NWO-IRTG 95-420 (Melly S. Oitzl).

\section{REFERENCES}

1. van Oers HJ, de Kloet ER, Whelan T, Levine S. Maternal deprivation effect on the infant's neural stress markers is reversed by tactile stimulation and feeding but not by suppressing corticosterone. J Neurosci (1998) 18(23):10171-9. 
2. Rosenfeld P, Gutierrez YA, Martin AM, Mallett HA, Alleva E, Levine S. Maternal regulation of the adrenocortical response in preweanling rats. Physiol Behav (1991) 50(4):661-71. doi:10.1016/0031-9384(91)90001-5

3. Sapolsky RM, Meaney MJ. Maturation of the adrenocortical stress response: neuroendocrine control mechanisms and the stress hyporesponsive period. Brain Res (1986) 396(1):64-76. doi:10.1016/0165-0173(86)90010-X

4. Schmidt MV, Enthoven L, van der Mark M, Levine S, de Kloet ER, Oitzl MS. The postnatal development of the hypothalamic-pituitary-adrenal axis in the mouse. Int J Dev Neurosci (2003) 21(3):125-32. doi:10.1016/S0736-5748(03)00030-3

5. Ader R, Grota LJ. Rhythmicity in the maternal behaviour of Rattus norvegicus. Anim Behav (1970) 18(1):144-50. doi:10.1016/0003-3472(70)90083-7

6. Schmidt MV, Oitzl MS, Levine S, de Kloet ER. The HPA system during the postnatal development of CD1 mice and the effects of maternal deprivation. Brain Res Dev Brain Res (2002) 139(1):39-49. doi:10.1016/S0165-3806(02)00519-9

7. Stanton ME, Gutierrez YR, Levine S. Maternal deprivation potentiates pituitaryadrenal stress responses in infant rats. Behav Neurosci (1988) 102(5):692-700. doi:10.1037/0735-7044.102.5.692

8. Nederhof E, Schmidt MV. Mismatch or cumulative stress: toward an integrated hypothesis of programming effects. Physiol Behav (2012) 106(5):691-700. doi:10.1016/j.physbeh.2011.12.008

9. Lehmann J, Feldon J. Long-term biobehavioral effects of maternal separation in the rat: consistent or confusing? Rev Neurosci (2000) 11(4):383-408. doi:10.1515/REVNEURO.2000.11.4.383

10. Claessens SE, Daskalakis NP, van der Veen R, Oitzl MS, de Kloet ER, Champagne DL. Development of individual differences in stress responsiveness: an overview of factors mediating the outcome of early life experiences. Psychopharmacology (Berl) (2011) 214(1):141-54. doi:10.1007/s00213-010-2118-y

11. Daskalakis NP, Bagot RC, Parker KJ, Vinkers CH, de Kloet ER. The three-hit concept of vulnerability and resilience: toward understanding adaptation to early-life adversity outcome. Psychoneuroendocrinology (2013) 38(9):1858-73. doi:10.1016/j.psyneuen.2013.06.008

12. Kosten TA, Kim JJ, Lee HJ. Early life manipulations alter learning and memory in rats. Neurosci Biobehav Rev (2012) 36(9):1985-2006. doi:10.1016/j.neubiorev. 2012.07.003

13. Carboni L, Becchi S, Piubelli C, Mallei A, Giambelli R, Razzoli M, et al. Earlylife stress and antidepressants modulate peripheral biomarkers in a geneenvironment rat model of depression. Prog Neuropsychopharmacol Biol Psychiatry (2010) 34(6):1037-48. doi:10.1016/j.pnpbp.2010.05.019

14. Neumann ID, Wigger A, Kromer S, Frank E, Landgraf R, Bosch OJ. Differential effects of periodic maternal separation on adult stress coping in a rat model of extremes in trait anxiety. Neuroscience (2005) 132(3):867-77. doi:10.1016/j.neuroscience.2005.01.034

15. Ellenbroek BA, Sluyter F, Cools AR. The role of genetic and early environmental factors in determining apomorphine susceptibility. Psychopharmacology (Berl) (2000) 148(2):124-31. doi:10.1007/s002130050033

16. Daskalakis NP, Claessens SE, Laboyrie JJ, Enthoven L, Oitzl MS, Champagne DL, et al. The newborn rat's stress system readily habituates to repeated and prolonged maternal separation, while continuing to respond to stressors in context dependent fashion. Horm Behav (2011) 60(2):165-76. doi:10.1016/j.yhbeh. 2011.04 .003

17. Enthoven L, Oitzl MS, Koning N, van der Mark M, de Kloet ER. Hypothalamicpituitary-adrenal axis activity of newborn mice rapidly desensitizes to repeated maternal absence but becomes highly responsive to novelty. Endocrinology (2008) 149(12):6366-77. doi:10.1210/en.2008-0238

18. Daskalakis NP, Diamantopoulou A, Claessens SE, Remmers E, Tjalve M, Oitzl MS, et al. Early experience of a novel-environment in isolation primes a fearful phenotype characterized by persistent amygdala activation. Psychoneuroendocrinology (2014) 39:39-57. doi:10.1016/j.psyneuen.2013.09.021

19. Hotchkiss AK, Pyter LM, Neigh GN, Nelson RJ. Nyctohemeral differences in response to restraint stress in CD-1 and C57BL/6 mice. Physiol Behav (2004) 80(4):441-7. doi:10.1016/j.physbeh.2003.09.010

20. Bouwknecht JA, Paylor R. Behavioral and physiological mouse assays for anxiety: a survey in nine mouse strains. Behav Brain Res (2002) 136(2):489-501. doi:10.1016/S0166-4328(02)00200-0

21. Dellu F, Contarino A, Simon H, Koob GF, Gold LH. Genetic differences in response to novelty and spatial memory using a two-trial recognition task in mice. Neurobiol Learn Mem (2000) 73(1):31-48. doi:10.1006/nlme.1999.3919
22. Heyser CJ, McDonald JS, Polis IY, Gold LH. Strain distribution of mice in discriminated Y-maze avoidance learning: genetic and procedural differences. Behav Neurosci (1999) 113(1):91-102. doi:10.1037/0735-7044.113.1.91

23. Millstein RA, Ralph RJ, Yang RJ, Holmes A. Effects of repeated maternal separation on prepulse inhibition of startle across inbred mouse strains. Genes Brain Behav (2006) 5(4):346-54. doi:10.1111/j.1601-183X.2005.00172.x

24. Millstein RA, Holmes A. Effects of repeated maternal separation on anxiety- and depression-related phenotypes in different mouse strains. Neurosci Biobehav Rev (2007) 31(1):3-17. doi:10.1016/j.neubiorev.2006.05.003

25. Parfitt DB, Levin JK, Saltstein KP, Klayman AS, Greer LM, Helmreich DL. Differential early rearing environments can accentuate or attenuate the responses to stress in male C57BL/6 mice. Brain Res (2004) 1016(1):111-8. doi:10.1016/j. brainres.2004.04.077

26. Parfitt DB, Walton JR, Corriveau EA, Helmreich DL. Early life stress effects on adult stress-induced corticosterone secretion and anxiety-like behavior in the C57BL/6 mouse are not as robust as initially thought. Horm Behav (2007) 52(4):417-26. doi:10.1016/j.yhbeh.2007.06.002

27. Romeo RD, Mueller A, Sisti HM, Ogawa S, McEwen BS, Brake WG. Anxiety and fear behaviors in adult male and female C57BL/ 6 mice are modulated by maternal separation. Horm Behav (2003) 43(5):561-7. doi:10.1016/S0018-506X(03) 00063-1

28. Martini M, Valverde O. A single episode of maternal deprivation impairs the motivation for cocaine in adolescent mice. Psychopharmacology (Berl) (2012) 219(1):149-58. doi:10.1007/s00213-011-2385-2

29. MacQueen GM, Ramakrishnan K, Ratnasingan R, Chen B, Young LT. Desipramine treatment reduces the long-term behavioural and neurochemical sequelae of early-life maternal separation. Int J Neuropsychopharmacol (2003) 6(4):391-6. doi:10.1017/S1461145703003729

30. Enthoven L, de Kloet ER, Oitzl MS. Effects of maternal deprivation of CD1 mice on performance in the water maze and swim stress. Behav Brain Res (2008) 187(1):195-9. doi:10.1016/j.bbr.2007.08.037

31. Fabricius K, Wortwein G, Pakkenberg B. The impact of maternal separation on adult mouse behaviour and on the total neuron number in the mouse hippocampus. Brain Struct Funct (2008) 212(5):403-16. doi:10.1007/s00429007-0169-6

32. van Heerden JH, Russell V, Korff A, Stein DJ, Illing N. Evaluating the behavioural consequences of early maternal separation in adult C57BL/6 mice; the importance of time. Behav Brain Res (2010) 207(2):332-42. doi:10.1016/j.bbr. 2009.10.015

33. Boasen JF, McPherson RJ, Hays SL, Juul SE, Gleason CA. Neonatal stress or morphine treatment alters adult mouse conditioned place preference. Neonatology (2009) 95(3):230-9. doi:10.1159/000165379

34. Weaver IC, Cervoni N, Champagne FA, D’Alessio AC, Sharma S, Seckl JR, et al. Epigenetic programming by maternal behavior. Nat Neurosci (2004) 7(8):847-54. doi:10.1038/nn1276

35. Schmidt M, Enthoven L, van Woezik JH, Levine S, de Kloet ER, Oitzl MS. The dynamics of the hypothalamic-pituitary-adrenal axis during maternal deprivation. J Neuroendocrinol (2004) 16(1):52-7. doi:10.1111/j.1365-2826.2004. 01123.x

36. Levine S, Huchton DM, Wiener SG, Rosenfeld P. Time course of the effect of maternal deprivation on the hypothalamic-pituitary-adrenal axis in the infant rat. Dev Psychobiol (1991) 24(8):547-58. doi:10.1002/dev.420240803

37. Okimoto DK, Blaus A, Schmidt MV, Gordon MK, Dent GW, Levine S. Differential expression of c-fos and tyrosine hydroxylase mRNA in the adrenal gland of the infant rat: evidence for an adrenal hyporesponsive period. Endocrinology (2002) 143(5):1717-25. doi:10.1210/endo.143.5.8819

38. Walker CD. Chemical sympathectomy and maternal separation affect neonatal stress responses and adrenal sensitivity to ACTH. Am J Physiol (1995) 268(5 Pt 2):R1281-8.

39. Enthoven L, Schmidt MV, Cheung YH, van der Mark MH, de Kloet ER, Oitzl MS. Ontogeny of the HPA axis of the CD1 mouse following $24 \mathrm{~h}$ maternal deprivation at pnd 3. Int J Dev Neurosci (2010) 28(2):217-24. doi:10.1016/j.ijdevneu. 2009.10.006

40. Schmidt MV, Levine S, Oitzl MS, van der Mark M, Muller MB, Holsboer F, et al. Glucocorticoid receptor blockade disinhibits pituitary-adrenal activity during the stress hyporesponsive period of the mouse. Endocrinology (2005) 146(3):1458-64. doi:10.1210/en.2004-1042 
41. Viau V, Sharma S, Meaney MJ. Changes in plasma adrenocorticotropin, corticosterone, corticosteroid-binding globulin, and hippocampal glucocorticoid receptor occupancy/translocation in rat pups in response to stress. J Neuroendocrinol (1996) 8(1):1-8. doi:10.1111/j.1365-2826.1996.tb00680.x

42. Schmidt MV, Liebl C, Sterlemann V, Ganea K, Hartmann J, Harbich D, et al. Neuropeptide Y mediates the initial hypothalamic-pituitary-adrenal response to maternal separation in the neonatal mouse. J Endocrinol (2008) 197(2):421-7. doi:10.1677/JOE-07-0634

43. Schmidt MV, Levine S, Alam S, Harbich D, Sterlemann V, Ganea K, et al. Metabolic signals modulate hypothalamic-pituitary-adrenal axis activation during maternal separation of the neonatal mouse. J Neuroendocrinol (2006) 18(11):865-74. doi:10.1111/j.1365-2826.2006.01482.x

44. Rodel HG, Meyer S, Prager G, Stefanski V, Hudson R. Litter size is negatively correlated with corticosterone levels in weanling and juvenile laboratory rats. Physiol Behav (2010) 99(5):644-50. doi:10.1016/j.physbeh.2010.01.032

45. Caldji C, Hellstrom IC, Zhang TY, Diorio J, Meaney MJ. Environmental regulation of the neural epigenome. FEBS Lett (2011) 585(13):2049-58. doi:10.1016/ j.febslet.2011.03.032
Conflict of Interest Statement: The authors declare that the research was conducted in the absence of any commercial or financial relationships that could be construed as a potential conflict of interest.

Received: 28 May 2014; accepted: 18 October 2014; published online: 05 November 2014.

Citation: Daskalakis NP, Enthoven L, Schoonheere E, de Kloet ER and Oitzl MS (2014) Immediate effects of maternal deprivation on the (re)activity of the HPA-axis differ in CD1 and C57Bl/6J mouse pups. Front. Endocrinol. 5:190. doi: 10.3389/fendo.2014.00190

This article was submitted to Neuroendocrine Science, a section of the journal Frontiers in Endocrinology.

Copyright (C) 2014 Daskalakis, Enthoven, Schoonheere, de Kloet and Oitzl. This is an open-access article distributed under the terms of the Creative Commons Attribution License (CC BY). The use, distribution or reproduction in other forums is permitted, provided the original author(s) or licensor are credited and that the original publication in this journal is cited, in accordance with accepted academic practice. No use, distribution or reproduction is permitted which does not comply with these terms. 